\title{
Strategi Peningkatan Kapasitas Masyarakat dalam Menghadapi Pandemi COVID-19 Guna Mendukung Keamanan Nasional di Kabupaten Pidie Jaya Aceh
}

\author{
Hafiz Surya Islami ${ }^{{ }^{*}}$, Iko Sarikanti Ponangsera ${ }^{1}$, Mir'atul Azizah ${ }^{1,}$ Yuli Subiakto ${ }^{2}$, \\ Eddy Azwar ${ }^{3}$ \\ ${ }^{1}$ Mahasiswa Program Studi Manajemen Bencana, Fakultas Keamanan Nasional, Universitas Pertahanan \\ ${ }^{2}$ Dosen Program Studi Manajemen Bencana, Fakultas Keamanan Nasional, Universitas Pertahanan \\ ${ }^{3}$ Dinas Kesehatan Kabupaten Pidie Jaya, Provinsi Aceh \\ *Email: hafizhsi257@gmail.com
}

DOI: https://doi.org/10.33369/pendipa.6.1.73-79

\section{ABSTRACT}

[The Strategy to Increase Community Capacity in Facing The COVID-19 Pandemic to Support National Security in Pidie Jaya Distric, Aceh] Coronavirus diseases-2019 or COVID-19 came from Wuhan City, China. Its virus found in the end of 2019. The spread is very fast and endemic almost all countries in the world, including Indonesia. COVID-19 affects at all sectors, including the economy, tourism industry, agriculture, education, health services, security, defense and many more. The COVID-19 pandemic is a non-natural disaster that must be faced together by involving all components of the nation. Pidie Jaya Regency is one of the areas in Aceh Province which is currently still working to deal with COVID-19. The purpose of this study is to find out the strategy of the Pidie Jaya Regency Government in increasing the community's capacity to deal with the COVID-19 pandemic. The method used is descriptive qualitative methods. Data sourced from literature, focus group discussion with the Pidie Jaya District Health Officer. Based on literature studies and interviews, the results show that until now the Pidie Jaya Regency government has increased the capacity of the community through socialization and education, enforcement of health protocol disciplines, vaccinations, preparing gampong (villages) that are more resilient against COVID19. In addition, the involvement of stakeholders both in government sector, society, academia and media. All work together to create a community in Pidie Jaya Regency who is healthy, safe and alert from COVID-19.

Keywords: COVID-19; capacity; national security; Kabupaten Pidie Jaya.

\begin{abstract}
ABSTRAK
Coronavirus diseases-2019 atau yang dikenal dengan COVID-19 berasal dari kota Wuhan, Provinsi Hubei China. Virus tersebut muncul pertama pada akhir tahun 2019. Penyebarannya sangat cepat dan mewabah hampir seluruh negara di dunia termasuk Indonesia. COVID-19 berdampak kepada segala sektor, baik ekonomi, industri pariwisata, pertanian, pendidikan, layanan kesehatan, kemanan dan pertahanan dan masih banyak lagi. Pandemi COVID-19 merupakan bencana non alam yang harus dihadapi secara bersama-sama dengan melibatkan seluruh komponen bangsa. Kabupaten Pidie Jaya merupakan salah satu wilayah di Provinsi Aceh yang sampai saat ini masih berupaya untuk menangani COVID-19. Tujuan dari penelitian ini adalah untuk mengetahui strategi dari Pemerintah Kabupaten Pidie Jaya dalam meningkatkan kapasitas masyarakat untuk menghadapi pandemi COVID-19. Metode yang digunakan yaitu metode kualitatif deskriptif. Data bersumber dari literatur, focus grup discussion dengan Dinas Kesehatan Kabupaten Pidie Jaya. Berdasarkan studi literatur dan wawancara didapatkan hasil bahwa sampai saat ini pemerintah Kabupaten Pidie Jaya meningkatkan kapasitas masyarakat melalui sosialisasi dan edukasi, penegakan disiplin protokol kesehatan, vaksinasi, menyiapkan gampong (desa) yang lebih tangguh terhadap COVID-19. Selain itu, pelibatan para stakeholder baik di sektor pemerintah,
\end{abstract}


masyarakat, akademis dan media. Semua saling bersinergi untuk mewujudkan masyarakat Kabupaten Pidie Jaya yang sehat, aman dan waspada dari COVID-19.

Kata kunci: COVID-19; kapasitas; keamanan nasional; Kabupaten Pidie Jaya.

\section{PENDAHULUAN}

Coronavirus disease-2019 atau COVID-19 pertama kali muncul di Kota Wuhan, Provinsi Hubei, China pada bulan Desember 2019. Virus ini berkembang sangat pesat menyebar ke berbagai kota di China, meluas ke Thailand dan Korea Selatan dalam waktu yang sangat singkat. World Health Organization (WHO), pada tanggal 12 Maret 2020 mengumumkan bahwa penyakit ini bernama COVID-19 yang disebabkan oleh virus SARS-CoV-2 (Susilo et al., 2020). Persebaran COVID- 19 sangat cepat dengan tingkat kematian (CFR) sebesar 4,3\% (Chen et al., 2020).

COVID-19 masuk ke Indonesia, diawali dengan dua warga Indonesia yang terpapar virus COVID-19 melaui kontak langsung dengan warga Negara Jepang yang sedang berkunjung ke Indonesia. kemudian pada tanggal 2 Maret 2020 Pemerintah Indonesia resmi menetapkan COVID-19 telah masuk kedalam Indonesia (Sukur et al., 2020).

Kasus COVID-19 semakin meningkat di Indonesia, hingga saat ini banyak ilmuwan yang melakukan penelitian tentang COVID-19 yang masih mewabah. Sampai hari ini, 20 April 2021 kasus COVID-19 di Indonesia sebanyak 1.609.300 orang dan kasus meninggal sebanyak 43.567 orang dan sembuh 1.461 .414 orang (Worldometers, 2021). Kasus COVID-19 terus meningkat dan perlu adanya upaya untuk menghentikan penyebaran kasus COVID-19.

Provinsi Aceh per tanggal 24 Februari 2021 berada pada wilayah dengan risiko rendah terhadap COVID-19 (zona kuning). Area tersebut meliputi Kab. Aceh Tenggara, Simeulue, Aceh Selatan, Nagan Raya, Aceh Barat Daya, Aceh Timur, Aceh Utara, Bireuen, Aceh Tengah, Gayo Lues, Pidie Jaya, Pidie, Aceh Barat, dan Kab. Aceh Singkil (Dinas Kesehatan Provinsi Aceh, 2021) .

Kabupaten Pidie Jaya merupakan salah satu kabupaten di Aceh dengan kasus COVID-19 terkonfirmasi positif sebanyak 230 kasus, total kematian 16 kasus, sembuh sebanyak 210 kasus, dan dalam perawatan 4 kasus per tanggal 25
Maret 2021 (Info Covid-19, 2021). Upaya mengurangi kasus positif COVID-19, diperluhkan peningkatan kapasitas masyarakat dalam menghadapi bahaya COVID-19. Menurut (Nugraha et al., 2016), kapasitas adalah kemampuan masyarakat melakukan tindakan pengurangan ancaman dan potensi kerugian akibat bencana.

Beberapa upaya dibutuhkan dalam meningkatkan kapasitas masyarakat. Strategi adalah kebijakan dan keputusan kunci yang digunakan untuk manajemen, yang memiliki dampak besar pada kinerja keuangan. Kebijakan dan keputusan ini biasanya melibatkan sumber daya yang penting dan tidak dapat diganti dengan mudah (Wahyudi, 1996).

Salah satu upaya atau strategi untuk meningkatkan kapasitas masyarakat dalam mengelola risiko bencana yang ada di wilayahnya sendiri bisa dilakukan dengan Kegiatan Pengurangan Risiko Bencana Berbasis Komunitas (Prihananto \& Muta'ali, 2013) .

Pandemi COVID-19 akan mempengaruhi keamanan nasional. Konsepsi mengenai keamanan nasional merupakan sebagai suatu kondisi yang menciptakan rasa aman, nyaman, damai, tentram dan tertib. Hal tersebut merujuk pada kebijakan publik yang dapat memastikan dan menjamin keselamatan dan keamanan negara dari segala bentuk ancaman, tantangan, hambatan dan gangguan (Darmono, 2010).

Pademi COVID-19 yang belum tahu kapan akan berakhir, sehingga sangat penting dilakukan penelitian tentang strategi peningkatan kapasitas masyarakat dalam menghadapi pandemi COVID19 guna mendukung keamanan nasional.

Tujuan dari penelitian ini adalah untuk mengetahui strategi dari Pemerintah Kabupaten Pidie Jaya dalam meningkatkan kapasitas masyarakat dalam menghadapi pandemi COVID19.

\section{METODE PENELITIAN}

Penelitian ini menggunakan metode kualitatif deskriptif. Data bersumber dari literatur, focus grup discussion dengan Dinas 
Kesehatan wilayah Kabupaten Pidie Jaya, Provinsi Aceh.

\section{HASIL DAN PEMBAHASAN \\ Kabupaten Pidie Jaya}

Kabupaten Pidie Jaya adalah salah satu Kabupaten di Provinsi Aceh, yang mana merupakan pemekaran dari Kabupaten Pidie. Kabupaten Pidie Jaya dengan Ibu Kota adalah Meurendu. Pidie Jaya terbentuk berdasarkan Undang Undang Nomor 7 Tahun 2007 tanggal 2 Januari 2007 (Undang-Undang, 2007). Gambaran wilayah Kabupaten Pidie Jaya dapat terlihat pada gambar 1 .

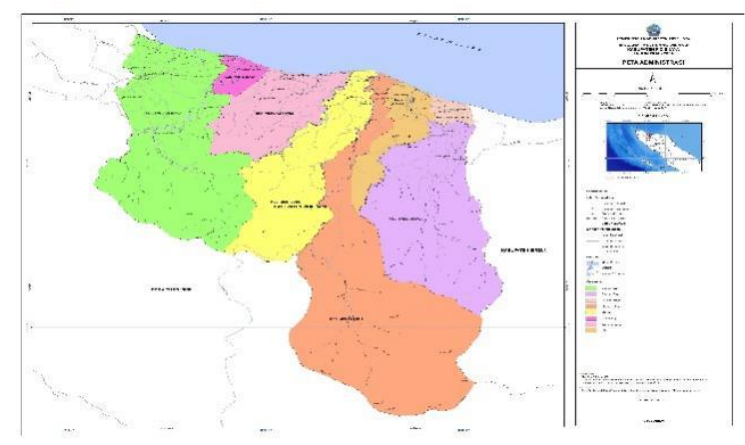

Gambar 1. Peta Wilayah Kabupaten Pidie Jaya

Berdasarkan gambar 1 tergambar bahwa wilayah Kabupaten Pidie Jaya Utara berbatasan dengan Selat Malaka. Bagian Selatan dan Barat berbatasan dengan Kabupaten Pidie dan bagian Timur berbatasan dengan Kabupaten Bireun,.

Letak geografis Kabupaten Pidie Jaya antara 9603'16,62" sampai dengan 96020'40,5" Bujur Timur dan 5018'6,607' sampai dengan 4056'42,1" Lintang Utara. Batas wilayah dari Kabupaten Pidie Jaya sebelah Utara adalah Selat Malaka, sebelah Timur Kabupaten Biereun, sebelah Selatan dan Barat adalah Kabupaten Pidie.

Masyarakat Kabupaten Pidie Jaya mayoritas beragama islam, dalam kehidupan sehari-hari mereka selalu mengedepankan ritme adat istiadat dan ajaran agama Islam sebagai pondasi dalam menjalankan kehidupan berbangsa dan bernegara.. Kemudian diterapkan dalam segala cabang kehidupan baik politik, sosial budaya, pendidikan tidak boleh bertentangan dengan ajaran Islam. Masyarakat Pidie Jaya sangat patuh dan taat dalam menjalankan ibadah Shalat lima waktu secara berjamaah di Masjid di lingkungan tempat tinggal masing-masing. Kemudian dalam memberikan pengajaran dan pengetahuan agama bagi anak-anak dan masyarakat secara rutin dilaksanakan di masjid.

\section{COVID-19 di Kabupaten Pidie Jaya}

Kabupaten Pidie Jaya saat ini menempati urutan ke-11 dengan jumlah kasus COVID-19 terbanyak di wilayah Provinsi Aceh (Info Covid19, 2021). Jumlah akumulasi kasus terlihat per tanggal 2 April 2021 seperti pada Tabel 1.

Tabel 1. Jumlah Kasus Covid - 19 di Kabupaten Pidie Jaya Per 2 April 2021

\begin{tabular}{cc}
\hline Kasus & Jumlah \\
\hline Positif & 230 \\
Sembuh & 210 \\
Perawatan & 4 \\
Meninggal & 16 \\
\hline
\end{tabular}

Berdasarkan Tabel 1 terlihat bahwa jumlah kasus sembuh dari COVID-19 adalah sebesar 210 orang dari 230 kasus atau sebanyak $91,30 \%$. Sedangkan jumlah kasus yang meninggal sebanyak 16 orang atau sebesar 6,96\% dan jumlah pasien COVID-19 yang masih dalam perawatan sebanyak 4 orang atau $1,74 \%$. Hal itu terlihat bahwa kasus sembuh lebih banyak dibandingkan kasus yang meninggal. Banyak faktor yang mempengaruhi, baik dari masyarakat, pemerintah dan pihak-pihak terkait.

Penilaian peta zona risiko COVID-19 ditentukan oleh tiga indikator yaitu epidemiologi, surveilans kesehatan masyarakat, dan pelayanan kesehatan. Kabupaten Pidie Jaya per tanggal 25 Maret 2021 masuk dalam zona oranye dan pada bulan Januari masuk pada zona kuning. Hal ini disebabkan oleh masyarakat yang terlena akan kondisi awal tahun 2021 Kabupaten Pidie Jaya memiliki 0 kasus COVID-19. Pelaksanaan protokol kesehatan masyarakat menurun, hal ini diperlihatkan dengan masuknya Kabupaten Pidie Jaya kedalam wilayah zona oranye.

Penanganan COVID-19 di Kabupaten Pidie Jaya Berdasarkan hasil focus grup discussion virtual dengan Kepala Dinas Kesehatan Kabupaten Pidie Jaya (Azwar, 2021) bahwa dalam menangani pandemi COVID-19, Bupati Kabupaten Pidie Jaya membentuk tim satgas 
penanggulangan COVID-19. Bupati juga membuat pos komando COVID-19 yang dipimpin langsung oleh Bupati Pidie Jaya.

Upaya yang telah dilaksanakan oleh Pemerintah Kabupaten Pidie Jaya dalam memutus rantai penularan COVID-19 antara lain adalah mengadakan apel kesiagaan dan disinfektan masal, pemeriksaan COVID-19, upaya tracing terhadap pasien terkonfirmasi COVID-19, mempersiapkan ruang isolasi bagi pasien tanpa gejala di Gedung Tgk Chik Pante Geulima Cot Trieng, edukasi ke masyarakat, memberikan dukungan sembako dan vitamin bagi keluarga yang menjalani isolasi mandiri.

Ketidakpatuhan dalam melaksanakan upaya pencegahan penularan pada COVID-19 dapat meningkatkan risiko tertular penyakit (R Elvi \& Alimansur, 2020).Penegakan disiplin sangat dibutuhkan, ada pihak yang mengingatkan jika masyarakat mulai lengah ataupun lupa dengan protokol kesehatan. Penegakan disiplin dilakukan oleh Tim Gugus Tugas COVID-19 bersama TNI, POLRI dan SATPOL PP. Razia dilakukan di beberapa fasilitas umum dalam upaya melaksanakan protokol kesehatan kepada seluruh masyarakat Kabupaten Pidie Jaya.

Secara rutin Pemerintah daerah melaksanakan operasi yustisi kepada masyarakat dan memberikan sanksi jika tidak mematuhi aturan yang sudah ditetapkan tentang penerapan protokol kesehatan. Sejauh ini pihak aparat tidak memberikan denda dalam bentuk uang jika ada yang melanggar, namun lebih kepada pembelajaran misalnya mereka membersihkan tempat ibadah, membaca surat pendek $\mathrm{Al}$ Qur'an, mengucapkan teks Pancasila, dan lain sebagainya.

Fasilitas Layanan Kesehatan sangat dibutuhkan sebagai rujukan COVID-19. Fasilitas Layanan Kesehatan yang dimiliki oleh Kabupaten Pidie Jaya adalah Rumah Sakit Umum, Puskesmas, Pos Kesehatan desa (Poskesdes), Puskesmas Pembantu (Pustu), Kantor Dinas Kesehatan. Berdasarkan hasil penelitian bahwa fasilitas layanan kesehatan memberikan pengaruh yang signifikan terhadap kepuasan pasien (Radito, 2014).

Pemerintah juga gencar memberikan vaksinasi kepada seluruh masyarakat Kabupaten Pidie Jaya. Masyarakat menerima vaksin COVID-19 Sinovac dengan 4 tahap yaitu tahap pertama diterima tanggal 1 Februari 2021 sebanyak 1874 dosis, tahap kedua diterima tanggal 24 Februari 2021 sebanyak 1444 dosis, tahap ketiga diterima tanggal 6 Maret 2021 sebanyak 880 dosis dan tahap keempat yang diterima tanggal 21 Maret 2021 sebanyak 1100 dosis.

Sasaran prioritas penerima vaksin yaitu tenaga kesehatan sebanyak 1.822 orang, petugas publik sebanyak 14.616 orang, dan lansia sebanyak 16.391. total sasaran vaksisnansi sebanyak 32.829. Pada tanggal 4 Mei 2021, pelaksanaan vaksin tahap pertama yang telah diterima sebanyak 3.243 dosis $(9,87 \%$ dari total sasaran vaksin) dan tahap kedua yang telah diterima sebanyak $2.750 \quad(8,37 \%$ dari total sasaran vaksin).

Sudah setahun lebih pandemi COVID-19 berjalan, penanganan di Kabupaten Pidie Jaya sejauh ini tidak mengalami kendala yang sangat berarti. Semua pihak saling bekerja sama untuk menangani wabah virus COVID-19. Dinas Kesehatan, Rumah Sakit, layanan kesehatan lainnya, Badan Penanggulangan Daerah, Tentara Nasional Indonesia, Polisi Republik Indonesia, tokoh agama, serta melibatkan akademisi (Azwar, 2021).

Strategi Peningkatan Kapasitas Masyarakat dalam Menghadapi COVID-19 Guna Mendukug Kemanan Nasional

Virus COVID-19 telah ditetapkan menjadi ancaman negara yang mengganggu keamanan nasional, dengan bentuk ancaman berupa bencana non-alam (Fernando, 2020). COVID-19 adalah bentuk ancaman terhadap keamanan nasional dan keselamatan bangsa indonesia, serta mempengaruhi kehidupan ekonomi dan sosial. Bencana ini tertuang pada Keputusan Presiden No 12 tahun 2020 tentang Penetapan Bencana Non-Alam Penyebaran Corona Virus Disease 2019 (COVID-19) sebagai Bencana Nasional (Kepres, 2020). Sesuai dengan Undang-undang 24 tahun 2007 dijelaskan bahwa bencana non alam merupakan bencana yang disebabkan oleh kejadian atau rangkaian pertiwa non alam diantaranya berupa gagal modernisasi, gagal teknologi, dan wabah penyakit. Masyarakat dengan kapasitas tinggi terhadap bencana maka akan lebih siap dan lebih bisa bertahan pada kondisi bencana, khususnya bencana COVID-19 
ini. Peningkatan kapasitas bertujuan untuk mengurangi risiko bencana yang terjadi, hal ini karena pengurangan risiko bencana adalah upaya mengatasi risiko bencana dengan dilakukan analisis dan kelola faktor penyebab terjadinya bencana, hal ini termasuk dalam meningkatkan kapasitas dan memperkecil kerentanan (Oxfam, 2012). Mewujudkan masyarakat yang tangguh bencana dengan kapasitas tinggi maka dibutuhkan strategi dalam upaya menghadapi COVID-19.

Strategi yang dilakukan Pemerintah Pidie Jaya dalam upaya peningkatan kapasitas masyarakat dalam menghadapi pandemi COVID19 terdapat dua poin utama, yaitu strategi untuk masyarakat dan strategi untuk lembaga. Hal tersebut seperti yang disampaikan pada penelitian sebelumnya bahwa upaya peningkatan kapasitas bisa ditinjau dari dua aspek, yaitu kapasitas masyarakat dan kapasitas lembaga.Kapasitas masyakat dipengaruhi oleh rencana aksi, budaya setempat, dan pengetahuan. Sedangkan kapasitas lembaga dipengaruhi oleh informasi, fasilitas, dan kepemimpinan serta program yang dijalankan (Nugraha et al., 2016).

Dalam aspek masyarakat, Pemerintah Daerah Kabupaten Pidie Jaya melakukan beberapa upaya untuk menekan angka penularan COVID-19, diantaranya adalah meningkatkan pengetahuan dan kesadaran masyarakat melalui sosialisasi kepatuhan melaksanakan protokol kesehatan, mengedukasi dan mengajak warga masyarakat untuk melaksanakan vaksinasi COVID-19.

Keuchik (Kepala Desa) merupakan perpanjangan tangan dari masyarakat dalam menyampaikan berita terkini kondisi masyarakat. Pembentukam posko satuan gugus tugas COVID-19 di Puskemas dan Gampong (desa) bertujuan agar masyarakat lebih mudah melakukan akses penanganan COVID-19.

Dinas Kesehatan mempunyai strategi dalam menghadapi COVID-19. Himbauan kepada masyarakat mengenai program memutus mata rantai pandemi COVID-19 melalui kampanye penerapan protokol kesehatan (Azwar, 2021). Penggunaan masker dapat mencegah masuknya droplet yang keluar saat batuk, bersin dan berbicara dengan tujuan tidak tertular dan menularkan, mencuci tangan dengan sabun atau disinfeksi dengan pembersih tangan yang mengandung $70 \%$ alkohol dan menghindari kerumumanan (Yanti et al., 2020).

Strategi lain dalam meningkatkan kapasitas masyarakat Kabupaten Pidie Jaya diantaranya adalah edukasi atau pelatihan petugas untuk pemulasaran jenazah COVID-19 tingkat Kabupaten Pidie Jaya di setiap gampong. Sebagian masyarakat Kabupaten Pidie Jaya tidak memiliki keberanian memandikan jenazah karena risko tertular COVID-19 dari jenazah pasien positif COVID-19.

Penyebaran COVID-19 melalui droplet atau percikan ketika berbicara atau batuk. Alasan utama inilah yang menjadi penyebab COVID-19 cepat menular (Wu et al., 2020). Kontak langsung dengan pasien COVID-19 pun berisiko tertular COVID-19.

Dengan inovasi edukasi masyarakat dengan program GENCAR COVID-19 (Gerakan Nakes Cegah COVID-19), GEMA (Gerakan Masker Aceh), GEMAS (Gerakan Masker Sekolah) dan GESID (Gerakan Edukasi Vaksinasi Covid-19). Gerakan ini pada dasarnya bertujuan agar masyarakat memperoleh pengetahuan tambahan terutama tentang kesehatan yang berkaitan dengan COVID-19 (Santoso \& Setyowati, 2020). Serta adanya peran aktif dari para relawan dari berbagai unsur organisasi masyarakat diantaranya Palang Merah Indonesia (PMI), Forum Pengurangan Risiko Bencana (FPRB), Search and Rescue (SAR), Radio Antar Penduduk Indonesia (RAPI), Ikatan Keluarga Anti Narkoba (IKAN), Pemberdayaan Kesejahteraan Keluarga (PKK), Public Service Centre (PSC), Persatuan Ahli Teknologi Laboratorium Kesehatan Indonesia (PATELKI), dan Komite Nasional Pemuda Indonesia (KNPI) dalam melakukan penanganan COVID-19.

Masyarakat di Pidie Jaya patuh menjalankan syariat Islam dalam kehidupannya yang sudah diatur sesuai hukum. Sehingga tokoh agama sangat membantu dalam merangkul masyarakat dalam upaya penanganan COVID-19 di Wilayah Pidie Jaya (Azwar, 2021). Peningkatan kapasitas masyarakat bisa melalui kegiatan pengurangan risiko bencana berbasis komunitas (Prihananto \& Muta'ali, 2013). 
Sinergitas ditujukan menghindari adanya tumpang tindih kebijakan dan program antar pihak yang berkepentingan dan menciptakan kemandirian masyarakat lebih cepat sehingga tidak selalu bergantung pada bantuan, terutama pemerintah (Rizkiyah et al., 2019). Dari aspek lembaga, Pemerintah Kabupaten Pidie Jaya melakukan beberapa strategi yaitu pembentukan gugus tugas dan penentuan posko COVID-19, penyiapan sarana dan prasana, pelibatan akademisi, media, dan stakeholder lainnya, mengedukasi protokol kesehatan dan melaksanakan vaksinasi, menggalakkan program 3T (Tracing, Testing dan Treatment). Konsep ini merujuk kepada sinergitas pentahelix. Para akademisi berfungsi untuk memberikan pengetahuan kepada masyarakat sehingga menimbulkan kesadaran masyarakat untuk mematuhi dan melaksanakan protokol kesehatan dengan baik dan benar.

Penegakan Peraturan Bupati Pidie Jaya Nomor 27 tahun 2020 tetang penerapan disiplin dan penegakan hukum protokol kesehatan sebagai upaya pengendalian COVID-19 dilakukan secara berkala yaitu melibatkan TNI dan POLRI. Peran media pun sangat penting dalam upaya penanggulangan COVID-19. Media sebagai perpanjangan tangan dalam penyampaian pesan dan informasi terhadap masyarakat. Dengan terlibatnya media, berharap agar masyarakat lebih mematuhi protokol kesehatan dan edukasi masyarakat terhadap wabah COVID19. Penyampaian informasi melalui baliho dan media sosial juga dilaksanakan.

Konsep kemanan nasional saat ini tidak hanya keamanan secara militer, namun berkembang pula keamanan insani. Masyarakat aman dan tenang dari pandemi merupakan wujud keamanan insani, yang mana bebas dari rasa ketakutan yaitu ketakutan terhadap bencana. Konsep kemanan pendekatan yang berpusat pada keamanan individu oleh UNDP kemudian dikembangkan dengan tujuh komponen yang saling bergantung satu sama lain, yaitu; ekonomi, makanan, kesehatan, lingkungan, pribadi, masyarakat, dan keamanan politik (Tadjbakhsh \& Chenoy, 2007).

\section{KESIMPULAN}

Kabupten Pidie Jaya saat ini masih berjuang untuk menangani pandemi COVID-19. Salah satu strategi yang dilakukan pemerintah Kabupten Pidie Jaya dalam menangani pandemik COVID-19 adalah meningkatkan masyarakat melalui kegiatan sosialisasi, edukasi, penegakan disiplin pelaksanaan protokol kesehatan, melakukan 3T dan vaksinasi dalam rangka mencapai herd immunity.

Pemerintah Daerah juga merangkul para stake holder dalam menangani pandemi COVID19. Pelibatan pemerintah, masyarakat, akdemisi, media dan pihak terkait lainnya sangat membantu masyarakat Kabupaten Pidie Jaya merasa lebih aman. Tenang dan tetap waspada terhadap COVID-19. Sehingga kemanan insani dan kemanan nasional secara umum dapat terwujud.

\section{DAFTAR PUSTAKA}

Azwar, E. (2021). Strategi Peningkatan Kapasitas Masyarakat Kabupaten Pidie Jaya Dalam Menghadapi Bencana Alam dan Pandemi Covid-19 Guna Mendukung Keamanan Nasional. Universitas Pertahanan RI.

Chen, B., Zhong, H., Ni, Y., Liu, L., Zhong, J., \& $\mathrm{Su}, \mathrm{X}$. (2020). Epidemiological Trends of Coronavirus Disease 2019 in China. Frontiers in Medicine, 7, 1-11. https://doi.org/https://doi.org/10.3389/fmed. 2020.00259

Darmono, B. (2010). Konsep dan Sistem Keamanan Nasional Indonesia. Jurnal Ketahanan Nasional, 15(1), 2-41.

Dinas Kesehatan Provinsi Aceh. (2021). Zona Kuning Meluas di Aceh, Kasus Baru Covid19 Bertambah 26 Orang. https://dinkes.acehprov.go.id/news/read/202 1/02/24/622/zona-kuning-meluas-di-acehkasus-baru-covid-19-bertambah-26orang.html

Fernando, Z. J. (2020). Pancasila sebagai Ideologi untuk Pertahanan dan Keamanan Nasional pada Pandemi COVID-19. Jurnal Kajian Lembaga Ketahanan Nasional Republik Indonesia, 8(3).

Info Covid-19. (2021). Aceh Tanggap Covid-19. 
https://covid19.acehprov.go.id/

Kepres, R. (2020). Keputusan Presiden RI Nomor 12 Tentang Penetapan Bencana Non-Alam Penyebaran Corona Virus Disease 2019 (COVID-19).

Nugraha, J., Nugraheni, F., \& Kurniawan, I. N. (2016). Model Kapasitas Masyarakat Dalam Menghadapi Bencana Menggunakan Analisis Regresi Logistik Ordinal. Eksakta, 16(1), 17-26.

Oxfam. (2012). Analisis Kerentanan dan Kapasitas Partisipatif Oxfam: Sebuah Pedoman Praktisi. Oxfam Indonesia.

Prihananto, F. G., \& Muta'ali, L. (2013). Kapasitas Masyarakat Dalam Upaya Pengurangan Risiko Bencana Berbasis Komunitas Di Desa Wonolelo Kecamatan Pleret Kabupaten Bantul. Jurnal Bumi Indonesia, 2(4).

R Elvi, Q., \& Alimansur, M. (2020). ). Prevention Efforts With Compliance To The Prevention Of Transmission Of Covid19 To Covid Volunteer. JPH RECODE, 4(1), 81-87.

Radito, T. A. (2014). Analisis Pengaruh Kualitas Pelayanan dan Fasilitas Kesehatan Terhadap Kepuasan Pasien Puskemas. Jurnal Ilmu Manajemen, 11(2).

Rizkiyah, P., Liyushiana, L., \& Herman, H. (2019). Sinergitas Pentahelix Dalam Pemulihan Pariwisata Pasca Bencana Erupsi Gunung Api Sinabung Di Kabupaten Karo, Sumatera Utara. Jurnal IPTA, 7(2), 247. https://doi.org/10.24843/ipta.2019.v07.i02. p15
Santoso, P., \& Setyowati, N. (2020). Hubungan Tingkat Pengetahuan Masyarakat Dengan Tindakan Preventif Covid-19. Jurnal Keperawatan Jiwa, 8(4), 565-570.

Sukur, M. H., Haris, B. K., \& Faradillahisari, R. N. (2020). Penanganan Pelayanan Kesehatan di Masa Pandemi Covid-19 dalam Perspektif Hukum Kesehatan. Hukum Kesehatan. Jurnal Hukum Inicio Legis, 1(1).

Tadjbakhsh, S., \& Chenoy, A. M. (2007). Human Security: Concepts and Implication. Routledge.

Undang-Undang, R. (2007). Undang Undang Nomor 7 Tahun 2007 tanggal 2 Januari 2007 Tentang Pembentukan Kabupaten Pidie Jaya di Provinsi NAD.

Wahyudi, A. S. (1996). Manajemen Strategi. Binarupa Aksara.

Worldometers. (2021). Total Kasus Covid 19 di Indonesia (Live). https://www.worldometers.info/coronavirus /country/indonesia/

Wu, Y. C., Chen, C. S., \& Chan, Y. J. (2020). The outbreak of COVID-19: An Overview. Journal of the Chinese Medical Association, 83(3), 217-220. https://doi.org/https://doi.org/10.1097/JCM A.00000000 00000270

Yanti, N. P. E. D. N., Wisnawa, I. M. A. D., Agustina, G. A., Diantari, N. P. D., \& Diantari, N. P. A. (2020). Gambaran Pengetahuan Masyarakat tentang COVID19 dan Perilaku Masyarakat di Masa Pandemi COVID-19. Jurnal Keperawatan Jiwa, 8(3). 